\title{
A systematic review of lost-time injuries in the global mining industry
}

\author{
Behdin Nowrouzi-Kia ${ }^{\mathrm{a}, *}$, Basem Gohar ${ }^{\mathrm{a}}$, Jennifer Casole ${ }^{\mathrm{b}}$, Carla Chidu $^{\mathrm{c}}$, Jennifer Dumond ${ }^{\mathrm{d}}$, \\ Alicia McDougalle and Behnam Nowrouzi-Kia ${ }^{\mathrm{c}}$ \\ ${ }^{a}$ Laurentian University, Sudbury, ON, Canada \\ ${ }^{\mathrm{b}}$ Loretto College, Toronto, ON, Canada \\ ${ }^{\mathrm{c}}$ McMaster University, Hamilton, ON, Canada \\ ${ }^{\mathrm{d}}$ Northern Ontario School of Medicine, Laurentian University, Sudbury, ON, Canada \\ ${ }^{\mathrm{e}}$ University of Manitoba, Winnipeg, MB, Canada
}

Received 21 December 2016

Accepted 7 September 2017

\begin{abstract}
.
BACKGROUND: Mining is a hazardous occupation with elevated rates of lost-time injury and disability.

OBJECTIVE: The purpose of this study is twofold: 1) To identify the type of lost-time injuries in the mining workforce, regardless of the kind of mining and 2) To examine the antecedent factors to the occupational injury (lost-time injuries).

METHODS: We identified and extracted primary papers related to lost-time injuries in the mining sector by conducting a systematic search of the electronic literature in the eight health and related databases.

RESULTS: We critically reviewed nine articles in the mining sector that examined lost-time injuries. Musculoskeletal injuries (hand, back, limbs, fractures, lacerations and muscle contusions), slips and falls were identified as types of lost-time injuries. The review identified the following antecedent factors related to lost-time injuries: the mining work environment (underground mining), being male, age, working with mining equipment, organizational size, falling objects, disease status, job training and lack of occupational safety management teams, recovery time, social supports, access to health services, pre-injury health status and susceptibility to injury.
\end{abstract}

DISCUSSIONS: The mining sector is a hazardous environment that increases workers' susceptibility to occupational injuries. There is a need to create and implement monitoring systems of lost-time injuries to implement prevention programs.

Keywords: Work disability, health and safety, occupation, injury

\section{Introduction}

Globally, mining is regarded as a high-risk occupation [1], and despite substantial progress in the area of occupational health and safety, in many nations, mining remains the industry where occupational injuries occur most often [2]. Occupational injuries have significant ramifications on the health of workers and the socioeconomic fabric of the country, yet they draw little public attention in Asia (China $[3,4]$ and

\footnotetext{
*Address for correspondence: Behdin Nowrouzi-Kia, Laurentian University, Sudbury, Ontario, Canada. Tel: +1 705626 4554; E-mail: behdin@gmail.com.
}

India [5-7]), Europe [8, 9], Africa [10-12] and South America [13]. Occupational injury rates vary considerably by country and are rarely comparable in part due to differences in legislation, availability of injury records (source of lost-time injury claim) and severity of the injury. The type and other characteristics of work-related injuries will vary with the severity of cases, which reflects the duration of workdays lost, and which is distinct from country to country. The mining industry accounts for a substantial proportion of these injuries, particularly fatal injuries and mining has been considered one of the world's most dangerous occupations [14, 15]. Furthermore, unsafe working conditions are often due to mine workers 
getting exposed to dust and gasses, fires, falling objects, and interaction with machinery among other things, resulting in both fatal and nonfatal injuries [16].

Mining lost-time injuries are complex and characterized by several factors including personal, workplace, compensation and health care system factors $[17,18]$. The severity of injuries is a less-used measure (e.g., statistics based on the workdays, statutory days, and restricted workdays per case of injury or illness charged to a single incident) [19]. Losttime injuries are a helpful metric of overall health and safety in a mine. Tracking lost-time injuries may facilitate identifying variables such as the use of personal protective equipment, occupational health and safety management systems, the efficient use of first aid and rapid access to medical care, or organizational policies concerning return to work and recovery [20]. Also, the mining work environment is inhibited by the absence of natural light, fresh air and open space and the undesirable presence of high temperatures, humidity, dust, fumes, noise and rock stresses. The inherent risks associated with these occupational hazards may trigger workplace injuries in mining worksites. Due to these occupational hazards, the risk inherent in mining may trigger work injury [1].

The purpose of this study is twofold: 1) To identify the type of lost-time injuries in the mining workforce, regardless of the kind of mining and 2) To examine the antecedent factors to the occupational injury (losttime injuries).

\section{Methods}

A health research librarian aided in developing and implementing search strategies to identify relevant literature related to mining lost-time injuries. A PICO framework was used to facilitate and refine the search strategy related to lost-time injury in mining. Published research was sought in the following databases and years: Ovid Medline, Embase, PsychINFO, CINAHL, Compendex, GEOBASE, GeoRef, and INSPEC. All articles were restricted to the English language and to human studies. The approach was modified according to the requirements of each database (for the full search strategy, please see Appendix). The search syntax was verified with the assistance of a second health librarian using the Canadian Agency for Drugs and Technologies in Health Peer Review Checklist for Search Strategies
[21]. Once the search strategies were finalized, a health librarian conducted the search on December 9,2015 , and the search results were updated on July 17, 2016.

\subsection{Study selection}

Articles were included in this review based on inclusion of assessment of occupational injury (specially lost-time injury) in mining and related to understanding a worker's risk for injury due to physical, chemical, biological, and psychological factors or a combination of factors. Furthermore, the study reported on accidental work-related injuries sustained at/within the workplace; and the study took place in a mining context excluding the United States of America (we have prepared a separate systematic review on the topic that is currently submitted for peer-review). Furthermore, we found no studies from the Americas or Asia that included all of the above mentioned criteria for this review.

Data synthesis involved a mixture of descriptive summaries of the included methodological research papers. Data extracted from research articles that described a summary of measures (odds ratios, difference in means, incident rate ratios) including lost-time injuries at the workplace were grouped and analyzed by study design (e.g., experimental, and observational designs). From this analysis, we prepared a descriptive analysis of the included studies and examined patterns in occupational injury in mining occurring at the workplace as a result of physical, chemical, biological and psychological factors or a combination of factors.

Studies were excluded if they reported on intentional (self-harm) work related injuries sustained at/within the workplace, if the studies did not cite occupational injuries in any mining workforce or if the studies occurred outside of a mining context. Conference proceedings, abstracts, editorials and/or commentaries were excluded as they do not provide sufficient information required for this review.

\subsection{Data extraction, management, and methodology}

A specifically designed data extraction form has been developed and entered using the Systematic Review Data Repository (U.S. Department of Health and Human Services) to record relevant literature related to lost-time injuries. 
For the first phase of screening, two reviewers read the titles and abstracts of all the citations from the electronic database searches and removed all citations not related to lost-time injuries in the mining industry. For the second phase of screening, if the title or abstract indicated that the study might meet the inclusion criteria then each reviewer individually examined the full article; any conflicting views were resolved by consultation between the reviewers, or by seeking advice from other experts on the team. Studies failing to meet these inclusion criteria were excluded from this review.

The extracted data included in the repository included study properties (author names, publication year, country of study, study setting, study design, sample size, methods of measuring lost-time injury, type of mining, location of mining site). Furthermore, we included workers' characteristics (mean age, sex, work experience, mining work environment) as well as a risk of bias assessment. Due to the heterogeneity of study designs, worker cohorts and variability of outcome measure related to lost-time injury, a metaanalytical approach was not feasible.

\subsection{Assessment of study quality, risk of bias in included papers}

The Critical Appraisal Skills Programme (CASP) checklist [22] was used to evaluate study quality and risk of bias by overseeing the assessment of validity and reliability of included studies (See Table 1). The following ten questions from the CASP checklist were used to grade and evaluate the studies: 1) Did the study address a clearly focused issue? 2) Did the authors use an appropriate method to answer their question? 3) Was the cohort recruited in an acceptable way? 4) Was the exposure accurately measured to minimize bias? 5) Was the outcome accurately measured to minimize bias? 6a) Have the authors identified all important confounding factors? 6b) Have they [the authors] taken account of the confounding factors in the design and/or analysis? 7a) Was the follow-up of subjects complete enough? 7b) Was the follow-up of subjects long enough? 8) What are the results of this study? 9) How precise are the results? 10) Do you believe the results? The CASP checklists may be applied to various study designs including systematic reviews, RCTs, cohort, and case-control studies, which will allow for the assessment of the range of study designs that may be included in this systematic review [23]. Two researchers (BNK and BG) applied the CASP check- lists to the included studies. Disagreements were discussed, and resolved through consensus with the research team.

\section{Results}

A total of 1,736 articles were retrieved before duplicate removal. A total of 42 articles were removed as duplicates. Of these, nine articles were included in this systematic review (Fig. 1). The studies reported examining lost-time injuries in Europe, Africa, and Oceania. The mean CASP score was $6.4(\mathrm{SD}=0.72)$ with a range of scores from 5 to 7 . All studies examined measurable lost-time injuries in the mining sector (See Table 1).

\subsection{European studies}

A Spanish study found 212 accidents that took place between 1982 and 2006 in the Catalonia [24]. For mining injuries (all sectors) or fatalities, 25.5\% were precipitated by workers being stuck between objects. Furthermore, $19.3 \%$ were a result of objects falling or collapsing onto workers, and $13.2 \%$ were due to people falling at different levels. The study found that the first event leading to a lost-time injury was generated by an environmental condition in both surface and underground mining [24]. These environmental conditions resulted from the location of the occupational accident. Moreover, these conditions could have been modified at that point in time (e.g., low lighting, wet floor, or cramped conditions) [24]. Environmental conditions were essentially due to deficiencies in the preventive system of mining workplaces since working conditions depend chiefly on whether companies have established adequate supervision, offered job training, and ensured proper occupational health and safety procedures.

In the coal mining industry, a study out of Wales reported on 58 hand injuries over a three-year (1980-1983) period, of which 52 lost-time records were obtained [25]. The top three causes of lost-time hand injuries were falling rock or coal $(34.5 \%)$, a moving cable belt or chain $(25.9 \%)$, and other falling or moving mining implements $(25.9 \%)$. The most common cause of hand injury was the crushed, compound fracture of the terminal phalangeal area of the digit, with or without pulp loss. Seven workers (13\%) returned to work within four weeks, 29 between four and 12 weeks, nine between 12 and 26 weeks, and seven between 26 and 52 weeks [25]. 
Table 1

Study characteristics of lost-time injury studies

\begin{tabular}{|c|c|c|c|c|c|c|}
\hline Author, year & $\begin{array}{l}\text { Sample size and } \\
\text { Years examined }\end{array}$ & $\begin{array}{l}\text { Typing of mining } \\
\text { and location }\end{array}$ & $\begin{array}{l}\text { Type of injury } \\
\text { assessed }\end{array}$ & $\begin{array}{c}\text { Database(s) used } \\
\text { for analysis of } \\
\text { lost-time injury }\end{array}$ & Evaluation of study & $\mathrm{CASP}^{+}$Grade \\
\hline $\begin{array}{l}\text { Calys-Tagoe, } \\
2015\end{array}$ & $\begin{array}{l}\text { - Cross-sectional - } \\
404 \text { miners }\end{array}$ & $\begin{array}{l}\text { Artisanal and } \\
\text { small-scale gold } \\
\text { mining in Tarkwa } \\
\text { mining in Ghana } \\
\text { AFRICA }\end{array}$ & $\begin{array}{l}\text { - No specific } \\
\text { injuries, but } \\
\text { severity was } \\
\text { measured based } \\
\text { on days missed }\end{array}$ & $\begin{array}{l}\text { Cross-sectional } \\
\text { survey looking at } \\
\text { miners based on } \\
\text { demographic } \\
\text { factors, gender, } \\
\text { work experience, } \\
\text { reported cause of } \\
\text { injury, and type of } \\
\text { work in the mine } \\
\text { (excavation, } \\
\text { crushing sifting, } \\
\text { washing, } \\
\text { amalgamation, } \\
\text { burning, or other) }\end{array}$ & $\begin{array}{l}\text { - This study's findings } \\
\text { describe that type of } \\
\text { work, level of } \\
\text { experience, gender, } \\
\text { and workplace } \\
\text { climate plays a } \\
\text { significant role in a } \\
\text { workplace injury. } \\
\text { - Information } \\
\text { included self-report } \\
\text { which may have } \\
\text { recall bias } \\
\text { - Study's purpose, } \\
\text { design, analysis and } \\
\text { tables appear to be } \\
\text { in order and easy to } \\
\text { follow. }\end{array}$ & $7 / 10$ \\
\hline $\begin{array}{l}\text { Hull, Leigh, } \\
\text { Driscool \& } \\
\text { Mandryk, } \\
1996\end{array}$ & $\begin{array}{l}\text { - Administrative } \\
\text { data for the period } \\
\text { of July } 1,1986 \text {, to } \\
\text { June } 30,1990\end{array}$ & $\begin{array}{l}\text { 21,372 lost-time } \\
\text { injury claims } \\
\text { Australia } \\
\text { OCEANIA }\end{array}$ & $\begin{array}{l}\text { - non-fatal injury } \\
\text { involving one or } \\
\text { more working } \\
\text { days lost as a } \\
\text { result of the injury } \\
\text { that occurred in } \\
\text { underground } \\
\text { mines, and that } \\
\text { did not occur on } \\
\text { the journey to or } \\
\text { from work }\end{array}$ & $\begin{array}{l}\text { The New South } \\
\text { Wales Joint Coal } \\
\text { Board computer } \\
\text { based } \\
\text { accident/incident } \\
\text { reporting system }\end{array}$ & $\begin{array}{l}\text { - Measured severity } \\
\text { of injury by four } \\
\text { types. Between } \\
\text { 1986-1990, the } \\
\text { number of lost-time } \\
\text { injury days per } \\
\text { 100,000 tonnes of } \\
\text { raw coal production } \\
\text { declined by } 73 \% \text {. } \\
\text { - Over the same } \\
\text { period, } 16 \% \text { (more } \\
\text { than } 20 \text { days off } \\
\text { work) of all } \\
\text { lost-time injury } \\
\text { claims in } \\
\text { underground mines } \\
\text { resulted in } 75 \% \text { of } \\
\text { the total days lost. }\end{array}$ & $7 / 10$ \\
\hline $\begin{array}{c}\text { Laflamme, } \\
1996\end{array}$ & $\begin{array}{l}\text { - Retrospective } \\
\text { longitudinal } \\
\text { analysis from } \\
1980 \text { to } 1990 \\
\text { - Male Swedish } \\
\text { miners }\end{array}$ & $\begin{array}{l}\text { Iron miners, } \\
\text { Sweden } \\
\text { EUROPE }\end{array}$ & $\begin{array}{l}\text { Looked at: } \\
\text { - non-specific } \\
\text { age-related } \\
\text { accidents } \\
\text { frequency } \\
\text { - Specific } \\
\text { age-related } \\
\text { accident } \\
\text { frequency } \\
\text { - Age-related } \\
\text { accident severity }\end{array}$ & $\begin{array}{l}\text { - For Accidents: } \\
\text { The Information } \\
\text { System on } \\
\text { Occupational } \\
\text { Injuries } \\
\text { maintained by } \\
\text { Sweden's } \\
\text { National Board of } \\
\text { Occupational } \\
\text { Safety and Health } \\
\text { - For Exposed } \\
\text { Workers: Swedish } \\
\text { Census data }\end{array}$ & $\begin{array}{l}\text { - In this specific } \\
\text { population, it } \\
\text { appears, as there is } \\
\text { a strong correlation } \\
\text { between increased } \\
\text { age and injury } \\
\text { prevalence and } \\
\text { severity. } \\
\text { - Study's purpose, } \\
\text { design, analysis, } \\
\text { and tables appear to } \\
\text { be in order and easy } \\
\text { to follow. } \\
\text { - Caution about the } \\
\text { age of the data and } \\
\text { potential changes to } \\
\text { regulations. }\end{array}$ & $6 / 10$ \\
\hline
\end{tabular}


Table 1

(Continued)

\begin{tabular}{|c|c|c|c|c|c|c|}
\hline Author, year & $\begin{array}{l}\text { Sample size and } \\
\text { Years examined }\end{array}$ & $\begin{array}{l}\text { Typing of mining } \\
\text { and location }\end{array}$ & $\begin{array}{l}\text { Type of injury } \\
\text { assessed }\end{array}$ & $\begin{array}{l}\text { Database(s) used for } \\
\text { analysis of lost-time } \\
\text { injury }\end{array}$ & Evaluation of study & $\mathrm{CASP}^{+}$Grade \\
\hline Leigh, 1990 & $\begin{array}{l}\text { - Cross-sectional } \\
\text { study between } \\
1986 \text { and } 1988 \\
\text { - Used incident } \\
\text { rates of accidents } \\
\text { vs. actual persons } \\
\text { - 23487 incidents }\end{array}$ & $\begin{array}{l}\text { - Coal mining, New } \\
\text { South Wales, } \\
\text { Australia } \\
\text { OCEANIA } \\
\end{array}$ & $\begin{array}{l}\text { - No specific } \\
\text { injuries, but } \\
\text { examined them } \\
\text { based on } \\
\text { fatalities, missed } \\
\text { vs. non-missed } \\
\text { work days }\end{array}$ & $\begin{array}{l}\text { - Cross-sectional } \\
\text { received from the } \\
\text { Joint Cal Board } \\
\text { reporting system }\end{array}$ & $\begin{array}{l}\text { - Main findings } \\
\text { suggest that } \\
\text { underground miners } \\
\text { are at higher risk } \\
\text { than non- } \\
\text { underground. } \\
\text { Furthermore, they } \\
\text { recommend a closer } \\
\text { look at age, work } \\
\text { experience, part of } \\
\text { the body that is } \\
\text { injured, type of } \\
\text { accidents, and shift } \\
\text { type for } \\
\text { management and } \\
\text { prevention } \\
\text { purposes. } \\
\text { - Study's purpose, } \\
\text { design, analysis, } \\
\text { and tables appear to } \\
\text { be in order and easy } \\
\text { to follow. Caution } \\
\text { about the age of the } \\
\text { data and potential } \\
\text { changes to } \\
\text { regulations. }\end{array}$ & s. \\
\hline Morgan, 1985 & $\begin{array}{l}\text { - Prospective study } \\
\text { - } 58 \text { coal miners }\end{array}$ & $\begin{array}{l}- \text { Coal miners in } \\
\text { South Wales } \\
\text { EUROPE }\end{array}$ & $\begin{array}{l}\text { - Hand injuries of } \\
\text { workers with } \\
\text { records of the } \\
\text { time off work }\end{array}$ & $\begin{array}{l}\text { - Prospective - Those } \\
\text { who attended the } \\
\text { Royal Gwent } \\
\text { Hospital with serious } \\
\text { hand injuries between } \\
1980 \text { and } 1983\end{array}$ & $\begin{array}{l}\text { - Findings suggest } \\
\text { that cause of } \\
\text { accidents is mainly } \\
\text { environmental - } \\
\text { working } \\
\text { underground which } \\
\text { then was much less } \\
\text { predictable than } \\
\text { present times. } \\
\text { - First, this study has } \\
\text { a limited sample } \\
\text { size, although } \\
\text { clinically significant } \\
\text { from an employer's } \\
\text { perspective } \\
\text { - Second, this study } \\
\text { is over } 30 \text { years old, } \\
\text { and therefore, I am } \\
\text { naively assuming } \\
\text { that safety } \\
\text { management has } \\
\text { improved since } \\
\text { then. Not to } \\
\text { mention coal } \\
\text { mining is not as } \\
\text { prevalent these } \\
\text { days. } \\
\text { - Study's purpose, } \\
\text { design, analysis and } \\
\text { tables appear to be } \\
\text { in order and easy to } \\
\text { follow. }\end{array}$ & t \\
\hline
\end{tabular}


Table 1

(Continued)

\begin{tabular}{|c|c|c|c|c|c|c|}
\hline Author, year & $\begin{array}{l}\text { Sample size and } \\
\text { Years examined }\end{array}$ & $\begin{array}{l}\text { Typing of mining } \\
\text { and location }\end{array}$ & $\begin{array}{l}\text { Type of injury } \\
\text { assessed }\end{array}$ & $\begin{array}{l}\text { Database(s) used for } \\
\text { analysis of lost-time } \\
\text { injury }\end{array}$ & Evaluation of study & $\mathrm{CASP}^{+}$Grade \\
\hline $\begin{array}{c}\text { Murray, } \\
2005\end{array}$ & $\begin{array}{l}\text { - Retrospective } \\
\text { - Focus of the } \\
\text { study was on HIV } \\
\text { and work-related } \\
\text { injury } \\
\text { - Total sample was } \\
\text { 7827; } 1661 \text { were } \\
\text { HIV positive, and } \\
6166 \text { were HIV } \\
\text { negative }\end{array}$ & $\begin{array}{l}\text { Gold mining }-4 \\
\text { gold mines within } \\
50 \mathrm{~km} \text { radius from } \\
\text { Johannesburg, } \\
\text { South Africa } \\
\text { AFRICA }\end{array}$ & $\begin{array}{l}\text { - Any injury that } \\
\text { led to the absence } \\
\text { of the miner for } \\
\text { over one day }\end{array}$ & $\begin{array}{l}\text { - Routinely collected } \\
\text { data from the mine } \\
\text { medical records for } \\
\text { the miners (re: HIV) - } \\
\text { Work-related injury } \\
\text { data was obtained } \\
\text { from the Rand Mutual } \\
\text { Assurance Company. } \\
\text { Insurers were not } \\
\text { aware of HIV }\end{array}$ & $\begin{array}{l}\text { - Overall, } \\
\text { HIV-positive miners } \\
\text { had higher } \\
\text { work-related injury } \\
\text { than HIV-negative, } \\
\text { although not severe } \\
\text { 1 - Their findings } \\
\text { suggest that } \\
\text { HIV-positive miners } \\
\text { are risk-takers, but } \\
\text { they suggest it's due } \\
\text { to psychological } \\
\text { consequences } \\
\text { related to learning } \\
\text { about the disease. } \\
\text { - Study's purpose, } \\
\text { design, analysis, } \\
\text { and tables appear to } \\
\text { be in order and easy } \\
\text { to follow. }\end{array}$ & s \\
\hline Poplin, 2008 & $\begin{array}{l}\text { - Comparison of } \\
\text { international data } \\
\text { between two } \\
\text { countries (not } \\
\text { limited to sample) } \\
\text { between } 1996 \text { and } \\
2003\end{array}$ & $\begin{array}{l}\text {-Coal mining } \\
\text { International: } \\
\text { USA \& Australia } \\
\text { (Queensland and } \\
\text { New South Wales) } \\
\text { NORTH } \\
\text { AMERICA \& } \\
\text { AUSTRALIA }\end{array}$ & $\begin{array}{l}\text { - No specific } \\
\text { injuries but } \\
\text { measured } \\
\text { lost-time } \\
\end{array}$ & $\begin{array}{l}\text { USA: Mine Safety and } \\
\text { Health } \\
\text { Administration's } \\
\text { (MSHA) Accident, } \\
\text { Illness and Injury } \\
\text { (AII) databases and } \\
\text { from Employment } \\
\text { and Address (E \&A) } \\
\text { files; Queensland } \\
\text { Department of } \\
\text { Natural Resources } \\
\text { and Mines; New } \\
\text { South Wales Coal } \\
\text { Services, Pty Ltd. } \\
\end{array}$ & $\begin{array}{l}\text { - The study's findings } \\
\text { demonstrate an } \\
\text { overall decline in } \\
\text { lost time injuries. } \\
\text { Declines were } \\
\text { noted in New South } \\
\text { Wales. As this study } \\
\text { sought to examine } \\
\text { regulatory } \\
\text { approaches between } \\
\text { these countries, } \\
\text { Australia's } \\
\text { risk-based health } \\
\text { and safety } \\
\text { regulations suggests } \\
\text { more decline in lost } \\
\text { time. However, the } \\
\text { authors do point out } \\
\text { heterogeneity in } \\
\text { collecting } \\
\text { information that } \\
\text { should be } \\
\text { considered with the } \\
\text { study's implications } \\
\text { - Study's purpose, } \\
\text { design, analysis, } \\
\text { and tables appear to } \\
\text { be in order and easy } \\
\text { to follow. }\end{array}$ & to \\
\hline
\end{tabular}


Table 1

(Continued)

\begin{tabular}{|c|c|c|c|c|c|c|}
\hline Author, year & $\begin{array}{l}\text { Sample size and } \\
\text { Years examined }\end{array}$ & $\begin{array}{l}\text { Typing of mining } \\
\text { and location }\end{array}$ & $\begin{array}{l}\text { Type of injury } \\
\text { assessed }\end{array}$ & $\begin{array}{l}\text { Database(s) used for } \\
\text { analysis of lost-time } \\
\text { injury }\end{array}$ & Evaluation of study & $\mathrm{CASP}^{+}$Grade \\
\hline $\begin{array}{l}\text { Sanmiquel, } \\
2010\end{array}$ & $\begin{array}{l}\text { - Retrospective } \\
\text { Analysis } \\
\text { - Sample is } 212 \text { (73 } \\
\text { underground \& } \\
139 \text { "surface") } \\
\text { accidents } \\
\text { - Between } 1982 \\
\text { and } 2006\end{array}$ & $\begin{array}{l}\text { Spanish mining } \\
\text { sector. They did } \\
3 \text { not specify the } \\
\text { type of mining. } \\
\text { They looked at it } \\
\text { as a full sector } \\
\text { EUROPE }\end{array}$ & $\begin{array}{l}\text { - They first } \\
\text { determine the } \\
\text { level of closeness } \\
\text { of the accident } \\
\text { using } \\
\text { classification } \\
\text { system } \\
\text { highlighted in a } \\
\text { former study PE1, } \\
\text { PE2, and PE3 } \\
\text { describe the } \\
\text { preceding factors } \\
\text { related to an } \\
\text { accident along } \\
\text { with a } \\
\text { contributing } \\
\text { factor (below): } \\
\text { 1. Environmental } \\
\text { 2. Equipment } \\
\text { 3. Work practice } \\
\text { 4. Supervision } \\
\text { 5. Training } \\
\text { 6. Task error } \\
\text { 7. Medical } \\
\text { 8. Other }\end{array}$ & $\begin{array}{l}\text { National Institute of } \\
\text { Safety and Hygiene in } \\
\text { Spanish Work } \\
\text { (INSHT) }\end{array}$ & $\begin{array}{l}\text { - Briefly, the study's } \\
\text { findings reveal that } \\
\text { environmental factors } \\
\text { leading to the } \\
\text { accident are } \\
\text { predominant followed } \\
\text { by human behaviours, } \\
\text { such as work practice } \\
\text { - Failing to describe in } \\
\text { more detail the PE's } \\
\text { as previous research, } \\
\text { has led to some } \\
\text { confusion in } \\
\text { interpreting results of } \\
\text { this study. } \\
\text { - Also, given that this } \\
\text { was a retrospective } \\
\text { study, there is some } \\
\text { subjectivity as } \\
\text { measured by } \\
\text { inter-rater response } \\
\text { based on their } \\
\text { "interpretation" of } \\
\text { what has led to the } \\
\text { injury. They describe } \\
\text { a good inter-rater } \\
\text { reliability between } \\
\text { coders } 1 \text { and } 2, \text { but it } \\
\text { remains somewhat } \\
\text { biased } \\
\text { - Study's purpose was } \\
\text { clear, study's design } \\
\text { was clear, however, } \\
\text { poor procedural } \\
\text { reporting } \\
\text { - Abstract lacks } \\
\text { informative content }\end{array}$ & , \\
\hline $\begin{array}{l}\text { Sanmiquel, } \\
2014\end{array}$ & $\begin{array}{l}-71 \text { quarries (with } \\
\text { an estimation } \\
\text { error of almost } \\
12 \% \text { due to small } \\
\text { sample size } \\
\text { collected from a } \\
\text { population of } \\
\text { almost } 4000 \text { ) }\end{array}$ & $\begin{array}{l}\text { - Spanish industrial } \\
\text { and ornamental } \\
\text { stone mining } \\
\text { EUROPE }\end{array}$ & $\begin{array}{l}\text { - No specific } \\
\text { injuries, but } \\
\text { examined all } \\
\text { accidents that } \\
\text { caused at least one } \\
\text { workday absence }\end{array}$ & $\begin{array}{l}\text { Spanish Ministry of } \\
\text { Work and } \\
\text { Immigration annual } \\
\text { databases on } \\
\text { accidents in the } \\
\text { mining sector } \\
\text { between 2007-08 }\end{array}$ & $\begin{array}{l}\text { - Incident rates increase } \\
\text { in areas that have } \\
\text { reduced safety } \\
\text { management services } \\
\text { or poor } \\
\text { preventative/safety } \\
\text { management practices } \\
\text { - Their findings came } \\
\text { from averaging } \\
\text { categorical data as per } \\
\text { Likert scales, } \\
(1=\text { poor and } \\
5=\text { optimal) } \\
\text { - Abstract lacks } \\
\text { informative content } \\
\text { - Sample does not } \\
\text { seem to describe } \\
\text { persons, but rather } \\
\text { quarries, which in a } \\
\text { way misleading }\end{array}$ & r \\
\hline
\end{tabular}

\footnotetext{
${ }^{+}$Critical Appraisal Skills Programme.
} 


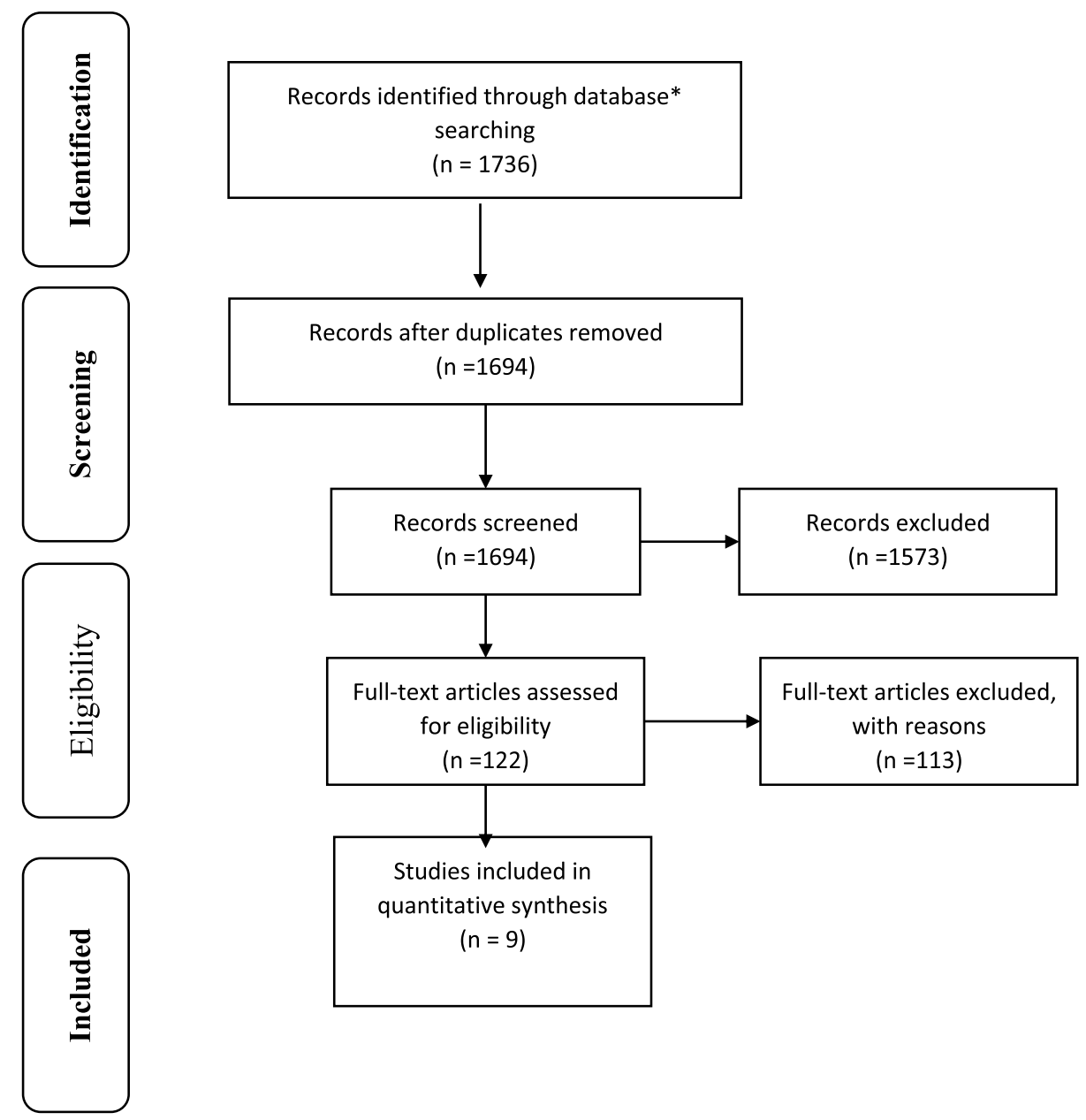

Fig. 1. PRISMA Flow Diagram of the Inclusion Process. * References included per database before removing duplicates: Medline (593), PsycInfo (54), CINAHL (63), EMBASE (193), Compendex (387), INSPEC (267), GEOBASE (11) and GeoRef (168).

In a Spanish study, San Miguel et al. (2014) reported on a sample of 71 surface mine sites in quarries of industrial and ornamental stone [9]. The study determined that sites with inadequate occupational health and safety management processes also have higher lost-time injuries [9]. San Miguel et al., (2014), developed a 41-item occupational safety management questionnaire that grouped items into four occupational health and safety categories. The Likert scale evaluated the respondent's agreement on various issues related to workplace prevention, organizational structure and general occupational health and safety in the workplace. The format of the five-level Likert item was: $0=$ Strong deficiencies; $1=$ Some deficiencies; 2=Can be improved; 3=Adequate; $4=$ Excellent. Results showed that the lowest quality of occupational safety management scores $(\mu=2.45$ on a five-point Likert scale with various weight factors given to each question) occurred in "Treatment Plants, Workshops and Storages" with less than 20 employees. Out of 2,449 accidents from 2007-2008, the mean lost-time was 24.6 days with $8.41 \%$ resulting in a minimum of 60 days of lost-time and an average of 107.8 days off work. The highest number of occurrences were attributed to physical over-exertion on the muscular-skeletal system, being hit by a falling object or hitting something as the result of a fall [9].

A Swedish study examined the age-related accident risks for male iron-ore miners over a ten-year period from 1980 to 1990 [26]. Laflamme and Blank (1996) reported that $6.3 \%$ of male miners experienced an accidental injury which was almost double that of male manufacturing workers at 3.6\%. Losttime injuries involving the upper body consisted of a total of 336 accidents, typically involving individuals 
who were 45 years old or younger. Lost-time injuries resulted in contusions and crushing injuries encountered from contact with flying or falling objects. Upper limb injuries were caused by the handling of various machinery and accounted for 150 accidents due to the manipulation of equipment. Those most susceptible to handling injuries were younger in age (25-34). Lower limb and back injuries (374) were due to missteps, falls or contact with flying or falling objects. These accidents were severe and involved skeletal injuries, sprain/strains, contusions and crushing injuries with lost-time average range of 15-30 days and up to more than 62 days. Sprain and strain injuries accounted for one hundred and seventy-five overexertion injuries to the lower neck and shoulders. These were less severe and resulted in an average of 15-30 days of lost-time. Age groups 55-65 were found to be most affected by a misstep and fall injuries as well as sprains/strains from overexertion. The overall results demonstrated that older miners (45 and over) experienced lower accident rates but had higher averages of lost days from work.

\subsection{African studies}

A South African study examined the relationship between HIV infection and work-related injuries in 7,827 workers at four gold mines [27]. The seroincident (concentration of HIV-virus in blood serum) cohort contained 1,661 HIV-positive miners; the seroconversion interval (is the duration of time in which HIV antibodies develop and become detectable) was less than one year for $58 \%$ and less than two years for 86\% [27]. The HIV-negative cohort contained 6,166 miners. Altogether there were 2,064 work-related injuries recorded in 1,659 of the miners. The overall work-related injury rate was higher in the HIVpositive than in the HIV-negative miners: 5.4 per 100 person-years at risk (95\% confidence interval (CI), 4.9-6.1) compared with 4.3 per100 person-years at risk (95\% CI, 4.1-4.5). There was a considerable difference in severity of injuries, as measured by days off work and permanent work disability. The proportion of injuries ending in permanent disability or prolonged time off work declined over the duration of the study. Time off work following permanent disability ranged from no days to more than one year. The time off was less than two weeks for $58 \%$ of the injuries, less than one month for $45 \%$, and less than six months for five percent [27].

A study by Calys-Tagoe et al. (2015) looked at artisanal and small-scale gold mining in the Tarkwa region of Ghana [28]. In 2014, hazards and physical injuries related to lost-time injuries were analyzed via personal interviews from 404 gold miners with various socio-demographic profiles. The highest rates of lost-time injuries involved employees with less than one year of mining experience (25.31 per 100 person years) and women (11.93 per 100 person years). The comparable average injury rate for all miners interviewed was 5.39 per 100 person years with $23.5 \%$ resulting in lost-time. From 121 injuries, $34.7 \%$ resulted in 4 to 14 days of absence, $34.7 \%$ reported more than 14 days off work, and $15 \%$ led to a month or more of absence. The majority of injuries were attributed to miners being hit by various falling objects (70\%) and from the use of machines or tools $(17.3 \%)$ while performing work activities. Such activities included excavation (58.7\%) and crushing activities $(23.1 \%)$ which were typically conducted by the men. The most prominent work-related injuries reported by the miners were lacerations to the upper and lower limbs (70\%) or the head, eyes, ears or face (17\%) [28].

\subsection{Oceanian studies}

Poplin and colleagues (2008) analyzed the annual lost-time injury rates from coal mines in Queensland (QLD) and New South Wales (NSW), Australia and compared these to injury rates in the United States [29]. Between 1996 and 2003, there were 39, 820 lost-time injuries reported in the US, 2,587 in QLD and 6,806 in NSW. In the same time period, the number of lost-time injuries declined by $37.7 \%$ in the US and by $68.4 \%$ in QLD and $65.7 \%$ in NSW. The greatest proportion of US mines employed less than ten miners (58.5\%) while Australian mines employed an average greater than 100 miners (64.0\%). Risk of injury was elevated in underground mines when compared to surface mines with this risk increasing with mine size, at a decreasing rate. The decline in losttime injuries per 100,000 miners was $20 \%$ in the US, $78 \%$ in QLD, and $52 \%$ in NSW. The incident rate ratio between 1996 and 2003 declined $11 \%$ in the US, 72\% in QLD and 44\% in NSW [29].

A study from New South Wales, Australia focused on the personal and environmental factors in coal mining accidents over a two and half year period between 1986 and 1988 [30]. In total, there were 23,487 reported incidents in NSW coal mines of which 16,770 resulted in lost-time injuries. A greater proportion of incidents occurred at underground mines $(90 \%)$ as opposed to open cut mines (10\%). 
The incident rate for underground mine workers was 638 per 1,000 and for open cut mine workers, 164 per 1,000 with the highest occurrences reported for miners that were between 30-39 years old $(34.7 \%)$. Furthermore, the most common types of injuries involved sprain/strains (50\%), followed by contusions/crush injuries (20\%) and open wounds (12\%). The most common body parts involved were the trunk (28\%), the upper limbs $(26 \%)$ and the lower limbs $(23 \%)$. Work activities such as manual handling, equipment repair/maintenance, and metal/mechanical trades work were associated with elevated mining accident rates. Environmental work factors that resulted in accidents included unstable ground (23\%), poor roofing (9\%) and low seam height (3\%). For underground mining, the average number of days away from work per injury was 23 , with this being 19 for open cut mining. An accumulated 135, 577 lost days per year were reported for underground miners and 13, 606 lost days per year were reported for open cut miners [30].

Another Australian study examined lost-time injuries in underground coal mining in NSW [31]. The study examined 21,372 (non-fatal) lost-time injuries between 1986 and 1990 using the severity of the injury as an outcome measure. The predictor variables belonged to four categories: 1) factors related to the susceptibility of the worker's body tissue to damage or repair, 2) factors related to the transfer of mechnical energy to the host by vehicle and environmental characteristics, 3) post-injury phase factors related to recovery time, social supports and access to health services, and 4) pre-injury phrase factors such as the worker's pre-injury health status and physical condition. Over the four-year period, the number of days lost per 100,000 tons of raw coal extracted decreased by $73 \%$. Moreover, a similar pattern (decrease of 65\%) was observed in compensation paid. Severe injuries (more than 20 days off work) resulted in $74 \%$ of the total compensation paid and $75 \%$ of the total lost-time days. Conversely, nonsevere injury cases contributed more to lost-time days and injuries and compensation paid, increasing from $18 \%$ to $43 \%$ over the same period [31].

\section{Discussion}

The purpose of this study was to identify the type of injuries in the global mining workforce and to examine the antecedent factors to the occupational injury. Musculoskeletal injuries (hand, back, limbs, frac- tures, lacerations, muscle contusions) and slips and falls were identified as types of lost-time injuries. The review identified the following antecedent factors related to lost-time injuries including the mining work environment (underground mining), being male, age, working with mining equipment, organizational size, falling objects, and disease status.

There are several limitations with this systematic review. The focus of our work on the subset of lost-time injuries which are part of a larger group of injuries that include non-lost-time injuries (e.g., referred to as restricted, medical treatment or first aid cases). the case of under-reporting lost-time injuries and inaccurate injury classification could alter the findings and conclusions of this work.

Due to the hazardous nature of the work, workers are susceptible to lost-time injuries. There is little debate that lost-time injuries persist as a significant health and socioeconomic problem for many nations [20]. In mining, lost-time injuries result in serious work disability and injury. Therefore, primary injury prevention is a vital public health objective that includes numerous approaches including regulation and monitoring [32]. Unfortunately, there is far less documented information in other countries (most notably non-western states) that are heavily involved in the mining industry and may have less strict processes for reporting injuries. In particular, countries such as China where workers are 37 times higher than American counterparts to be killed at work [33]. Therefore, tracking and monitoring of occupational health and safety objectives (including lost-time injuries) should be a primary responsibility of these governments, as it is in many countries that have stricter reporting policies [32].

Lost-time mining injuries are an important metric in understanding the predictors of occupational injury in the mining industry. To understand, compare, and prevent lost-time occupational injuries across mining sectors and countries, a uniform set of standards is warranted. Many countries have legislation, systems and processes in place to monitor and report injuries. One such system used is in the United States, the Mine Safety and Health Administration, an agency which administers the Federal Mine Safety and Health Act [34]. For instance, since 1978 (the first year MSHA operated under the Mine Act of 1977), 242 miners died in mining accidents. In 2015, this number decreased to 28 deaths [34]. One solution is to implement universal legislation and systems to create, maintain or reinforce occupational health and safety programs in a high-risk industry that is plagued 
by a lack of health and safety regulations [35]. For example, occupational health and safety legislation mandates the reporting of lost-time injuries in countries such as Australia and Canada. Such practices will help to prevent, identify and manage lost-time injuries and to comply with laws and regulations. Moreover, enforcement of existing legislation is also required in jurisdictions where laws already exist.

Aside from occupational health and safety legislation and policy implementation, statistical approaches may also be helpful to monitor lost time injuries in the mining industry. One approach has been a proactive statistical model to predict the number of accidents, total days lost and risk level of an underground coal mine [36]. This method may be used to develop a risk analysis method in examining the antecedent factors to lost-time injuries. The collection, monitoring and implementation of occupational health and safety management systems is warranted.

Despite our review of the lost-time injury literature, there is a limited number of studies that examined the mental health predictors in the mining workforce and its link to productivity [37-41]. The lack of literature is surprising given the rise of mental health problems in the working population [42] and the intimate relationship between many disease outcomes and mental health and well-being [43, 44]. Exacerbating matters are a lack of records (e.g., such as the Mine Safety and Health Administration Database in the United States and similar systems in other countries) and tracking of lost-time injuries in many countries that lack organized health and safety monitoring. The current systematic review identifies that there is limited information on factors that contribute to workplace lost-time injuries. Some factors (e.g., musculoskeletal predictors) $[45,46]$ are associated with certain health outcomes (e.g., lost-time injuries).

In countries without injury reporting and tracking (e.g., nations with emerging economies), there is a need to develop and design injury management systems to track, monitor and assess lost-time injuries. These should include centralized databases and tracking of all mine injuries across all mining countries including leading and lagging indicators (e.g., currently existing in the mining sectors in Australia, Europe and North America). These efforts also support longitudinal cohort studies to determine lost-time injury trends over time in these emerging economies. Therefore, continued study of these factors supports the creation and implementation of evidence-based prevention and intervention pro- grams aimed at preventing lost-time injuries in the mining industry. Further studies should be conducted to analyse studies not included in this study to further the creation of a universal system.

\section{Conflict of interest}

The authors have no conflict of interest to declare.

\section{References}

[1] Paul PS. Predictors of work injury in underground mines - an application of a logistic regression model. Min Sci \& Tech. 2009;19(3):282-9.

[2] Ural S, Demirkol S. Evaluation of occupational safety and health in surface mines. Safety Sci. 2008;46(6):1016-24.

[3] Chan EY, Griffiths SM. The epidemiology of mine accidents in China. Lancet. 2010;376(9741):575-7.

[4] Hongchang A. Mine accidents and china colliery safety early warning information. Adv Mat Res. 2012;461:329-32.

[5] Adams JSK, Raju R, Solomon V, Samuel P, Dutta AK, Rose $\mathrm{JS}$, et al. Increasing compliance with protective eyewear to reduce ocular injuries in stone-quarry workers in Tamil Nadu, India: A pragmatic, cluster randomised trial of a single education session versus an enhanced education package delivered over six months. Inj. 2013;44(1):118-25.

[6] Kunar BM, Bhattacherjee A, Chau N. Relationships of job hazards, lack of knowledge, alcohol use, health status and risk taking behavior to work injury of coal miners: A casecontrol study in India. J Occup Health. 2008;50(3):236-44.

[7] Maiti J, Khanzode VV, Ray PK. Severity analysis of Indian coal mine accidents - A retrospective study for 100 years. Safety Sci. 2009;47(7):1033-42.

[8] Sanmiquel L, Rossell JM, Vintro C. Study of Spanish mining accidents using data mining techniques. Safety Sci. 2015;75:49-55.

[9] Sanmiquel L, Rossell JM, Vintró C, Freijo M. Influence of occupational safety management on the incidence rate of occupational accidents in the Spanish industrial and ornamental stone mining. Work. 2014;49(2):307-14.

[10] Hansia MR, Dickinson D. Hearing protection device usage at a South African gold mine. Occup Med. 2010;60(1) (pp 72-74):Arte Number: kq114. ate of Pubaton: January 2010.

[11] Maiden RP. Managing trauma in the South African mining industry. Int J Emerg Ment Health. 2005;7(3):213-7.

[12] Nyantumbu B, Barber CM, Ross M, Curran AD, Fishwick D, Dias B, et al. Hand-arm vibration syndrome in South African gold miners. Occup Med. 2007;57(1):25-9.

[13] Brahm F, Singer M. Is more engaging safety training always better in reducing accidents? Evidence of self-selection from Chilean panel data. J Safety Res. 2013:85-92.

[14] Boniface R, Museru L, Munthali V, Lett R. Occupational injuries and fatalities in a tanzanite mine: Need to improve workers safety in Tanzania. Pan Afr Med J. 2013;120-5.

[15] Wang S, Li Y, Chi G, Xiao S, Ozanne-Smith J, Stevenson M, et al. Injury-related fatalities in China: An under-recognised public-health problem. Lancet. 2008;372(9651):1765-73.

[16] Karra VK. Analysis of non-fatal and fatal injury rates for mine operator and contractor employees and the 
influence of work location. J Safety Res. 2005;36(5): 413-21.

[17] Loisel P, Cote P. The Work Disability Paradigm and Its Public Health Implications. In: Loisel P, Anema JR, editors. Handbook of work disability New York, USA: Springer; 2013. pp. 59-67.

[18] Paul PS, Maiti J, Dasgupta S, Forjuoh SN. An epidemiological study of injury in mines: Implications for safety promotion. Int J Inj Contr Saf Promot. 2005;12(3):157-65.

[19] Ghosh AK, Bhattacherjee A, Chau N. Relationships of working conditions and individual characteristics to occupational injuries: A case-control study in coal miners. J Occup Health. 2004;46(6):470-80.

[20] Coleman PJ, Kerkering JC. Measuring mining safety with injury statistics: Lost workdays as indicators of risk. J Safety Res. 2007;38(5):523-33.

[21] Canadian Agency for Drugs and Technologies in Health. CADTH peer review checklist for search strategies Ottawa, Ontario, Canada: Canadian Agency for Drugs and Technologies in Health; 2013 Available from: https://www.cadth. ca/sites/default/files/is/Peer_review/CADTH\%20Peer\%20 Review\%20Checklist\%20for\%20Search\%20Strategies_e. pdf

[22] Critical Appraisal Skills Programme (CASP) Checklist. Critical Appraisal Skills Programme (CASP) Checklist Middle Way, Oxford, United Kingdom: CASP UK; 2016 Available from: http://www.casp-uk.net/\#!casp-toolschecklists/c18f8

[23] Khuu W, Chan V, Colantonio A. A systematic review protocol for measuring comorbidity in inpatient rehabilitation for non-traumatic brain injury. Syst Rev. 2015;4(1):1.

[24] Sanmiquel L, Freijo M, Edo J, Rossell JM. Analysis of work related accidents in the Spanish mining sector from 19822006. J Safety Res. 2010;41(1):1-7.

[25] Morgan WJ, Harrop SN. Hand injuries in south Wales coal miners. Br J Ind Med. 1985;42(12):844-7.

[26] Laflamme L, Blank VL. Age-related accident risks: Longitudinal study of Swedish iron ore miners. Am J Ind Med. 1996;30(4):479-87.

[27] Murray J, Sonnenberg P, Nelson G, Shearer S, Bester A, Begley A, et al. Effect of HIV on work-related injury rates in South African gold miners. AIDS. 2005;19(17):2019-24.

[28] Calys-Tagoe BNL, Ovadje L, Clarke E, Basu N, Robins T. Injury profiles associated with artisanal and small-scale gold mining in Tarkwa, Ghana. Int J Environ Res Publ Health. 2015;12(7):7922-37.

[29] Poplin GS, Miller HB, RangerMoore J, Bofinger CM, KurziusSpencer M, Harris RB, et al. International evaluation of injury rates in coal mining: A comparison of risk and compliance-based regulatory approaches. Safety Sci. 2008;46(8):1196-204.

[30] Leigh J, Mulder HB, Want GV, Fanrsworth NP, Morgan GG. Personal and environmental factors in coal mining accidents. Safety Sci. 1990;13(3):233-50.

[31] Hull BP, Leigh J, Driscoll TR, Mandryk J. Factors associated with occupational injury severity in the New South
Wales underground coal mining industry. Safety Sci. 1996;21(3):191-204.

[32] Weeks JL. Occupational health and safety regulation in the coal mining industry: Public health at the workplace. Annual Review of Public Health. 1991;12:195-207.

[33] Wang S, Zhang J-1. Study on coal mines accidents based on the grey relational analysis. J Coal Sci Eng. 2008;14(1): 81-4.

[34] Mine Safety and Health Administration (MSHA). Mission Washington, DC: United States Department of Labor; 2016 Available from: https://www.msha.gov/about/mission

[35] Chen JK, Zorigt D. Managing occupational health and safety in the mining industry. J Bus Res. 2013;66(11):2321-31.

[36] Sari M, Selcuk AS, Karpuz C, Duzgun HSB. Stochastic modeling of accident risks associated with an underground coal mine in Turkey. Safety Sci. 2009;47(1):78-87.

[37] Bailey SK, Haggarty J, Kelly S. Global absenteeism and presenteeism in mental health patients referred through primary care. Work. 2016;53(2):399-408.

[38] Ling R, Kelly B, Considine R, Tynan R, Searles A, Doran $\mathrm{CM}$. The economic impact of psychological distress in the Australian coal mining industry. J Occup Environ Med. 2016;58(5):e171-e6.

[39] Considine R, Tynan R, James C, Wiggers J, Lewin T, Inder $\mathrm{K}$, et al. The contribution of individual, social and work characteristics to employee mental health in a coal mining industry population. PLoS One. 2017;12(1):e0168445.

[40] Tynan RJ, Considine R, Rich JL, Skehan J, Wiggers J, Lewin TJ, et al. Help-seeking for mental health problems by employees in the Australian Mining Industry. BMC Health Serv Res. 2016;16(1):498.

[41] Tynan R, Considine R, Lewin T, James C, Inder K, Baker $\mathrm{TD}$, et al. Alcohol and other drug use in the Australian mining industry. Occupational and Enviromental Medicine. (under review_).

[42] Sairanen S, Matzanke D, Smeall D. The business case: Collaborating to help employees maintain their mental wellbeing. Healthc Pap. 2010;11:78-84.

[43] Cattrell A, Harris EC, Palmer KT, Kim M, Aylward M, Coggon D. Regional trends in awards of incapacity benefit by cause. Occup Med. 2011:kqr008.

[44] Murray CJ, Vos T, Lozano R, Naghavi M, Flaxman AD, Michaud C, et al. Disability-adjusted life years (DALYs) for 291 diseases and injuries in 21 regions, 1990-2010: A systematic analysis for the Global Burden of Disease Study 2010. Lancet. 2013;380(9859):2197-223.

[45] Widanarko B, Legg S, Stevenson M, Devereux J. Interaction between physical, psychosocial, and organisational work factors for low back symptoms and its consequences amongst Indonesian coal mining workers. Work. 2012;41(Supplement 1):6112-9.

[46] Howard B, Sesek R, Bloswick D. Typical whole body vibration exposure magnitudes encountered in the open pit mining industry. Work. 2009;34(3):297-303. 


\section{Appendix}

\section{MEDLINE}

((exp *"wounds \& injuries"/) OR ("wounds \& injuries")) OR ((exp *accidents, occupational/) OR (accidents, occupational/)) OR ((exp *occupational injuries/) OR (occupational injuries)) OR ((exp *accidents/) OR (accidents)) AND (exp*mining/) $=516$ (limited to ENGLISH only)

((exp *"wounds \& injuries"/) OR ("wounds \& injuries")) OR ((exp *accidents, occupational/) OR (accidents, occupational/)) OR ((exp *occupational injuries/) OR (occupational injuries)) OR ((exp*accidents/) OR (accidents)) AND (exp *mining/) AND $(\exp$ causality $/)=77$ (limited to ENGLISH only)

\section{PsycInfo Results}

(miner.mp or miners.mp) AND (exp working conditions/OR exp occupational safety/)

\section{CINAHL results}

("MH mining") AND (MH "Wounds \& Injuries+" OR (MH “Accidents, Occupational+") OR (MH "Accidents+")

\section{EMBASE Results}

((exp *mining/or miner/) AND (exp accident/OR exp injury/) AND (exp accident proneness/OR exp epidemiology/OR antecedent variable/))

\section{Compendex Results}

$(((((((\{$ Mining $\}$ WN CV $)))))$ AND (1969-2016 WN YR $))$ OR $(((((\{$ Miners $\}$ WN CV $))))$ AND
(1969-2016 WN YR)) OR $(((((\{$ Mines $\}$ WN CV $))))$ AND (1969-2016 WN YR)))) AND (((((\$injury)

WN ALL) AND (1969-2016 WN YR)) OR

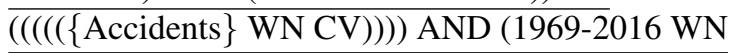
$\overline{\mathrm{YR}))))=}$

\section{Inspec Results}

(mining or mining industry or mineral processing industry) AND (injuries or accidents or accident prevention)

\section{GEOBASE Results}

$((((\{$ mining $\}$ WN CV OR $\{$ mining $\}$ WN RGI $)))$ AND (1973-2016 WN YR)) AND $(((((\{$ accident $\}$ WN CV OR \{accident $\}$ WN RGI))) AND (19732016 WN YR $))$ OR $((((\{$ accident prevention $\}$ WN $\overline{\text { CV OR \{accident prevention\} WN RGI })) \text { AND }}$ (1973-2016 WN YR)) OR ((( \{ accident, hazard, risk and related phenomena\} WN CV OR \{accident, hazard, risk and related phenomena $\}$ WN RGI))) AND (1973-2016 WN YR))))

\section{GeoRef Results}

$((((((((\{$ mining $\}$ WN CV $)))))$ AND (1785-2016 WN YR $))$ OR $(((((\{$ mines $\}$ WN CV $))))$ AND (1785 -2016 WN YR $))))$ AND $(((((\{$ accidents $\}$ WN CV $))))$ AND (1785-2016 WN YR))) $=168$ 